\title{
現本堂の構造上の問題等が長期利用に与える影響 \\ 仏教寺院の住職へのアンケート調査による \\ IMPACT OF STRUCTURAL ISSUES, etc. ON THE LONG-TERM USE OF CURRENT MAIN HALLS
}

A questionnaire survey of chief priests of Buddhist temples

\author{
佐々木 健*, 勝又英明** \\ Takeshi SASAKI and Hideaki KATSUMATA
}

\begin{abstract}
Impact of structural issues, etc. on the long-term use of main halls mainly indicates following 4 aspects.
(1) Structural issues have been found in two-thirds of current main halls.

(2) Structural issues in wooden main halls have gradually decreased in the 70 years since World War II.

(3) Wooden main halls are susceptible to rot and aging of structural materials due to the effect of rainwater and humidity.

(4) It is important to implement the necessary disaster measures and reinforcement after performing seismic diagnosis of wooden main halls.
\end{abstract}

\section{Keywords:Buddhist Temple, Main Hall, Regional Cultural Property, Maintenance for Restoration, Questionnaire Survey}

仏教寺院, 本堂, 地域文化財, 保存修理, アンケート調査

\section{1. はじめに}

\section{1 研究の背景と目的}

本稿は国指定文化財建造物を除く全国の寺院本堂の使用期間とそ の要因を検証する研究の続編である。前稿 ${ }^{1)}$ では住職へのアンケー 卜調查を通じて前本堂と現本堂の建立した時代や建替えた時代, 建 替え理由等から使用期間の要因を明らかにし, また, 現本堂の構造上 の問題注 1 ) 等が今後の使用予定期間に影響を与えることを指摘した。

一方,関野は関東大震災後の本堂の被害について東京市では地震 による倒壊を免れたが, 修繥を忠った古い本堂は著しく傾斜したと 指摘し, 加藤により同様の調査報告が阪神淡路大震災後にも行われ た注2)。このように, 古い本堂の地震による被害を軽減する為に維持 修繥は欠かせない。しかし, 建築の近代化に伴い 1960 年から 70 年代 頃まで非木造本堂が全国的に普及した注3) 反動で木造本堂の造営機 会と堂宮大工の減少を招き, 修理をせずに構造上の問題を放置した 古い本堂が各地でみられるようになった。また, 木造の寺社建築の減 少は技術者の技量低下注4) にも繋がる等, 古い本堂を長期利用する 為の建築環境は近年著しく変化した。東日本大震災後の日本建築学 会の提言注5) では災害による被害を最小限にとどめる補強や改修の 必要性が指摘され, 古い本堂でも不特定多数に利用される場合は安 全性の確保が期待される。現本堂は長期利用の結果, 将来価値が発見 され文化財となる可能性もあり,これら保存を目的とした修理注 6) も今後益々重要になると考えられる。

このように, 長期利用の中で大災害を経験する例もあり, 古い本堂 を長期利用寸る為に維持修繥は必要不可欠である。しかし, 前稿 ${ }^{1)}$
の本堂の使用期間に関する研究では, 構造上の問題の要因, 維持修繥 等, 現本堂の長期利用に与える影響を明らかにしていない。

そこで, 本稿では現本堂の建物種別や建立時代等だけでなく, 新た に実施した補足調查により,現本堂の構造上の問題の要因や維持修 繥, 災害対策と相談者等, 現本堂の長期利用へ与える影響を明らかに する。なお, 現本堂の使用期間を下記と定義する。

これまでの使用期間注7)：現本堂を建立後ここれまで使用した期間。 今後の使用予定期間: 住職の希望として今後, 現本堂を使用する予定 の期間。実際には後の住職の意向等で建替える場合もある。

想定使用期間：現本堂の最終的な使用期間は除却するまでわからな い為, 本稿では現本堂のこれまでの使用期間に今後の使用予定期間 を加算注 8) した期間を現本堂の想定使用期間とする。

\section{2 既往研究と本稿の位置づけ}

文化財建造物の保存修理に関して伊原は,明治・大正期に歴史的建 造物では小屋組をトラス架構に変える修理が行われたが，正福寺地 蔵堂の昭和修理を境に建立当時の技術や文化を伝える遺産として当 初に戻す修理になったと指摘し ${ }^{9}$,伝統的修理の方法が見直された。 歴史的建造物の修理について光井は,過去の災害後に様々な改良 や補強が行われたが本格的な補強に資金的問題がある場合は小修理 で建立当初の性能を保持する重要性を指摘した注9)。腰原らは関東 大震災による鎌倉社寺の被害に関する研究 ${ }^{11)}$ で,建物形式等と被害 の関係から伝統構法による木造社寺の被害の特長を明らかにした。

阪神淡路大震災後には伝統木造の寺社建築にも耐震補強による安 全性確保が重視されるようになり,宮本らは大正 2 年建立の本堂で

\footnotetext{
* 東京都市大学工学部建築学科 客員研究員 ·博士 (工学)

Visiting Researcher, Dept. of Architecture, Faculty of Engineering, Tokyo City

** 東京都市大学工学部建築学科 教授 · 博士 (工学) 
強度補強型改修の有効性を示した ${ }^{12)}$ 。また, 後藤は現行の建築基準法 では寺社建築等の軸組は考慮されずに無駄な補強や壁を加えること になる為, 寺社建築の構造特性に応じた建築基準法における新たな 構造計算の章立ての必要性を指摘した ${ }^{120)}$ 。一方, 角陸らは木造重要 文化財建造物の耐震補強設計の意志決定プロセスにて構造設計者を 主とした関係性に着目した ${ }^{14)}$ 。伝統的木造建築の構造的耐用年限に ついては関野らの研究で,柱の径が大きくなるに従い耐用年限も増 加すること等が示された注11)。このように, 文化財以外の古い本堂に も関連する保存修理の研究には主に, 修理方法の変遷, 災害と被害の 関係, 耐震補強と安全性確保, 現行の建築基準法への指摘等があった。

本研究では現本堂の長期利用へ与える影響を, 建物種別, 構造上の 問題の要因, 維持修繥, 災害対策と相談者等から明らかにする。

\section{2. 調查概要}

\section{1 調査対象}

本研究ではまず,全国 76,849 寺院のデータベース注 12$)$ を作成した。 また, 調查対象を伝統宗教注 ${ }^{13)}$ の仏教寺院とし, 国指定の国宝・重要 文化財の本堂を除外した結果, 対象は 74,584 寺院となった。この中 から無作為抽出法により 17,574 寺院を選定注 ${ }^{14)}$ し, 2007 年から 2012 年度に順次,郵送による基本アンケート調查(以下, 基本調查) ${ }^{\text {注 }}{ }^{15)}$ を 実施した結果, 2, 661 件の有効回答 (回答率 15. 1\%) 得た。更に 2013 年度は基本調查にて今後の調查に協力可能とした 1,778 寺院を対象 に補足調查を行い, 949 件の有効回答(回答率 $53 \%$ ) を得た（表 1 )。

\section{表 1 基本調査 · 補足調查の郵送結果}

\begin{tabular}{|c|c|c|c|c|c|c|c|c|c|}
\hline & \multirow[b]{2}{*}{ 調査対象 } & \multicolumn{4}{|c|}{ 基本調查 } & \multicolumn{4}{|c|}{ 補足調查 } \\
\hline & & 調查年度 & 郵送寺院 & 有効回答 & \begin{tabular}{|c|} 
地方別 \\
割合
\end{tabular} & 調查年度 & 郵送寺院 & 有効回答 & \begin{tabular}{|c|} 
地方別 \\
割合
\end{tabular} \\
\hline 全国 & \begin{tabular}{|l|l|}
784 件 \\
\end{tabular} & & \begin{tabular}{|l|l}
17,574 件 \\
\end{tabular} & \begin{tabular}{|l}
2,661 件 \\
\end{tabular} & $100.0 \%$ & & 1,778件 & 949件(53\%) & $100.0 \%$ \\
\hline 北海道 & 2.440 件 & \multirow{2}{*}{ 2012年度 } & 732件 & 107件 & $4.0 \%$ & & 76件 & 38 件 $(50 \%)$ & $4.0 \%$ \\
\hline 東北地方 & 5,221 件 & & 1,656 件 & 325件 & $12.2 \%$ & & 220件 & 110 件 $(50 \%)$ & $11.6 \%$ \\
\hline 関東6県 & \begin{tabular}{|l}
10,216 件 \\
\end{tabular} & 2008年度 & 2,556 件 & 356件 & $13.4 \%$ & & 236 件 & 121 件 $(51 \%)$ & $12.8 \%$ \\
\hline 東京都 & 2,748件 & 2007年度 & 1,851 件 & 418件 & $15.7 \%$ & & 233件 & 135 件(58\%) & $14.2 \%$ \\
\hline 中部地方 & \begin{tabular}{|l}
21,839 件 \\
\end{tabular} & 2010年度 & 4,363 件 & 597件 & $22.4 \%$ & & 401件 & 216 件(54\%) & $22.8 \%$ \\
\hline 近畿地方 & \begin{tabular}{|l|l|l}
15,854 件 \\
\end{tabular} & 2009年度 & 3,169 件 & 519件 & $19.5 \%$ & & 361 件 & 191件(53\%) & \begin{tabular}{|l|}
$20.1 \%$ \\
\end{tabular} \\
\hline 中国地方 & 6,286 件 & \multirow{3}{*}{ 2011年度 } & 1,255 件 & 1411件 & $5.3 \%$ & & 105件 & 54 件 $(51 \%)$ & $5.3 \%$ \\
\hline 四国地方 & 2,826 件 & & 564件 & 69件 & $2.6 \%$ & & 53件 & 26 件(49\%) & $2.7 \%$ \\
\hline 九州地方 & 7,157 件 & & 1,428 件 & 129件 & $4.8 \%$ & & 103件 & 58 件(56\%) & $6.1 \%$ \\
\hline
\end{tabular}

なお,補足調査の有効回答は基本調査の $1 / 3$ 弱となり,調査対象数 の違いから分析結果に誤差を生じる可能性が考えられる。そこで, 有効回答の地方別の構成を検証した結果, 全地方で概ね同一の傾向 を示した為,本稿では 2 種類の調査を元に分析を行うこととする。

\section{2 調査内容}

アンケートによる基本調査の内容は, 寺院の一般事項として寺院 名, 住所, 創立年, 宗派等とした。実態調査としては, 現本堂の建立年, 構造, 文化財種別 (指定, 登録), 規模 (面積), 今後の使用予定期間, 構 造上の問題等とした。

また, 補足調査の内容は, 現本堂の災害経験,災害による被害,屋根 莫材, 維持修繥, 構造上の問題とその要因,災害 (地震) 対策の内容, 災 害対策に関する相談者,屋根の莫替等とした(表 2 )。

表 2 基本調査・補足調査のアンケート項目

\begin{tabular}{|c|c|c|c|}
\hline \multirow[b]{2}{*}{ 基本調査 } & \multicolumn{2}{|c|}{ 寺院の一般事項 } & 寺院名、住所、創立年、宗派、防火指定等 \\
\hline & 実態調查 & 現本堂 & $\begin{array}{l}\text { 建立年、構造、規模(面積)、今後の使用予定期 } \\
\text { 間、構造上の問題、次の建替えで選択する構造 } \\
\text { 等、文化財(指定·登録)種別 }\end{array}$ \\
\hline \multirow{2}{*}{ 補足調查 } & \multicolumn{2}{|c|}{ 災害経験と対策 } & \begin{tabular}{|l} 
災害経験、災害による被害、災害(地震)対策の \\
内容、災害対策に関する相談者
\end{tabular} \\
\hline & \multicolumn{2}{|c|}{$\begin{array}{c}\text { 構造上の問題、維 } \\
\text { 持修繥 }\end{array}$} & $\begin{array}{l}\text { 構造上の問題、構造上の問題の要因、維持修 } \\
\text { 縇、屋根の莫替ええ等 }\end{array}$ \\
\hline
\end{tabular}

\section{3. 現本堂の建物種別と使用期間}

本研究では, 国指定文化財の現本堂を対象から除外した一方で, 地 域文化財注 16) (都道府県指定 12 棟, 市町村指定 59 棟, 国登録 11 棟) を含めた結果，A. 地域文化財は 82 棟 $(3 \%)$, B. 非建替え型は 747 棟 (28\%)，C. 地域文化財でも非建替え型でもない現本堂は 1,832 棟 (69\%) となった。地域文化財の現本堂の構造は 2 棟を除き全て木造 で，B. 非建替え型は，C. 地域文化財でも非建替え型でもない現本堂 より木造の割合が高い(表 3 )。

なお, 現本堂の 3 種類の建物種別 (A. 地域文化財, B. 非建替え型, C. 地域文化財でも非建替え型でもない)をそれぞれ下記と定義する。 地域文化財：国指定文化財を除く，国登録文化財，都道府県指定文化 財, 市町村指定文化財とする。

非建替え型注 ${ }^{17)}$ : 修理を繰り返して使用し続ける現本堂とする。 地域文化財でも非建替え型でもない：上記，「地域文化財」や「非建 替え型」に含まれない現本堂であり,この略表記を「その他」とする。

\section{表 3 現本堂の構造と建物種別}

\begin{tabular}{|c|c|c|c|c|c|}
\hline \multicolumn{2}{|c|}{ 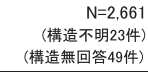 } & 計 & $\begin{array}{l}\text { A.地域文化財 } \\
\text { (非建替元型含む) }\end{array}$ & $\begin{array}{l}\text { B.非建替え型 } \\
\text { (地域文化財以外) }\end{array}$ & \begin{tabular}{|} 
C. 地域文化財でも非 \\
建替え型でもない
\end{tabular} \\
\hline \multicolumn{2}{|r|}{ 計 } & 2,661 棟 & 82 棟(100\%) & 747棟（100\%） & 1,832棟 (100\%) \\
\hline \multirow{3}{*}{\begin{tabular}{|l} 
構 \\
造
\end{tabular}} & 木造 & 2,098棟 & 80棟(98\%) & 609棟 (82\%) & 1,412 植 \\
\hline & 非木造 & 404棟 & 2棟 (2\%) & 102棟 (14\%) & 300 棟 (16\%) \\
\hline & 混構造 & 87棟 & 0棟 (0\%) & 18棟 (2\%) & 69 棟 (4\%) \\
\hline
\end{tabular}

\section{1 現本堂の建物種別と使用期間}

現本堂の建立した時代毎の分布は江戸以前 633 棟 (26\%), 明治 272 棟 (11\%), 大正から戦前注 ${ }^{18)} 307$ 棟 (13\%), 戦後 1, 231 棟 (50\%)だった。 また,A. 地域文化財の現本堂は全てが戦前の建立で江戸以前が約 6 割となり,B. 非建替え型は C. その他より戦前の建立が多い(表 4)。

なお, 文化財建造物が多い近畿地方 (県指定: 奈良 2 件, 滋賀 2 件, 京都 1 件)の現本堂では奈良や和歌山 (平均 150 年以上)より,これま での使用期間が比較的短い大阪 (平均 91.4 年) にて, 非建替え型の割 合が高かった。このように, 多くの文化財を有する近畿のような地域 においても, 文化財として価值が発見されない古い本堂は建替えが 進む可能性が考えられる。

\section{表 4 現本堂の建立した時代と建物種別}

\begin{tabular}{|c|c|c|c|c|c|}
\hline \multicolumn{2}{|c|}{ 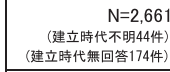 } & 計 & $\begin{array}{l}\text { A. 地域文化財 } \\
\text { (非建替え型含む) }\end{array}$ & $\begin{array}{l}\text { B. 非建替え型 } \\
\text { (地域文化財以外) }\end{array}$ & $\begin{array}{c}\text { C. 地域文化財でも } \\
\text { 非建替え型でもな } \\
\text { い }\end{array}$ \\
\hline \multicolumn{2}{|r|}{ 計 } & 2,661 棟 & 82 棟 (100\%) & 747棟 (100\%) & 1, 832棟 (100\%) \\
\hline \multirow{5}{*}{$\begin{array}{l}\text { 建 } \\
\frac{\text { 立 }}{\text { 寺 }} \\
\text { 代 }\end{array}$} & 江戸以前 & 633棟 & 47棟 (57\%) & 182棟 (24\%) & 404棟 (22\%) \\
\hline & 明治 & 272 棟 & 13棟 (16\%) & 88 棟 (12\%) & 171棟 (9\%) \\
\hline & 大正から戦前 & 307棟 & 11 棟 $(13 \%)$ & 98棟 (13\%) & 198棟 (11\%) \\
\hline & 戦後 & 1,231 棟 & 0棟 $(0 \%)$ & 331棟 (44\%) & 900 棟 (49\%) \\
\hline & わからない & 218 棟 & 11棟 (13\%) & 48棟 (7\%) & 159棟 (9\%) \\
\hline
\end{tabular}

次に, 現本堂の想定使用期間の割合は, A. 地域文化財や B. 非建替 え型では長期利用の傾向があり,C. その他とは違うものと推測した。

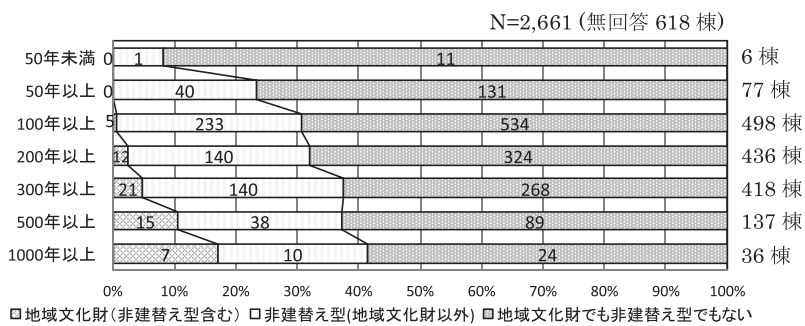

図 1 現本堂の想定使用期間と建物種別 
しかし,A. 地域文化財に関しては 200 年以上の想定使用期間から 徐々に割合が増えたものの, B. 非建替え型と C. その他は共に 100 年 以上の想定使用期間がそれぞれ 233 棟 (B. の 39\%), 534 棟 (C.の 39\%) でピークとなり,その後徐々に減った (図 1 )。このように, 当初推測 したような明確な違いが B. 非建替え型と C. その他の現本堂の想定 使用期間には見られず, 地域文化財だけが際立つ結果となり, 将来的 に価值が発見され文化財となる可能性のある非建替え型より, 既に 価值が発見された文化財の現本堂にて長期利用が期待されていた。

\section{2 現本堂の建物種別と構造上の問題}

現本堂の構造上の問題 (構造材の老朽化等) 注 ${ }^{19)}$ は, 問題あり 1,668 棟 (65\%), 問題なし 758 棟 (30\%), わからない 120 棟 (5\%) となり, $2 / 3$ の寺院にて, 住職が現本堂に構造上の問題を認識していた (表 5 )。

また, 構造上の問題のある割合は, 木造本堂の場合, 建物種別のC. その他で少し低いものの, 建立の古い A. 地域文化財と B. 非建替え型 は変わらず, 構造上の問題は建築種別に関係なく認識されていた。

表 5 現本堂の構造上の問題の有無と建物種別

\begin{tabular}{|c|c|c|c|c|c|c|c|c|}
\hline & \multirow{2}{*}{ 全体 } & \multirow{2}{*}{ A.地域文化財 } & \multicolumn{3}{|c|}{ B. 非建替元型 } & \multicolumn{3}{|c|}{ c. その他 } \\
\hline & & & 木造 & 非木造 & 不明等 & 木造 & 非木造 & 不明等 \\
\hline 母数 & 2,661 棟 & 估 & 609 棟 & 2棟 & & 1,412 棟 & 300 棟 & 120 棟 \\
\hline 無回答 & 2,546棟 (100\%) & 78棟(100\%) & 599棟(100\%) & $96(100 \%)$ & & $1,369(100 \%)$ & $276(100 \%)$ & \\
\hline 問題あり & \begin{tabular}{|l|}
1,668 棟(65\%) \\
\end{tabular} & 57棟(73\%) & 432棟(72\%) & $48(50 \%)$ & & $\begin{array}{l}913(67 \%) \\
\end{array}$ & $142(51 \%)$ & \\
\hline 問題なし & 758 棟(30\%) & 18棟(23\%) & 138棟(23\%) & $41(43 \%)$ & & $402(29 \%)$ & $118(42 \%)$ & \\
\hline つからない & 120 棟(5\%) & 3棟(4\%) & 29 棟(5\%) & $7(7 \%)$ & & $54(4 \%)$ & $19(7 \%)$ & \\
\hline
\end{tabular}

\section{4. 現本堂 (木造)の構造上の問題等と使用期間}

建立年の比較的新しい非木造の現本堂は, 構造上の問題の割合が 低く, 修理等の事例も少ない為, 本章では木造の現本堂の使用期間等 に与える要因を, 基本調査による現本堂の構造上の問題や規模等か ら検証する。木造の現本堂で構造上の問題が認識された割合は, 戦後 の建立では 5 割弱あったが, 戦前の建立では 8 割弱となり, それ以前 も変化はなかった(図 2)。

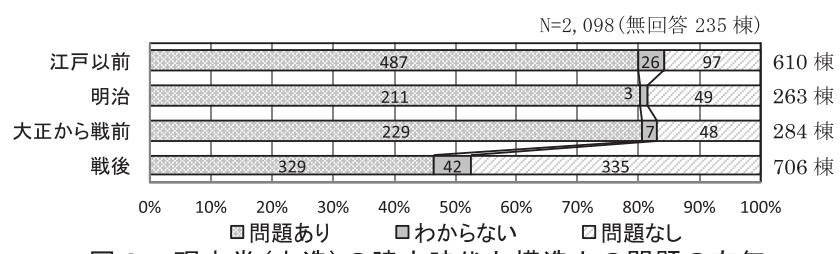

図 2 現本堂 (木造)の建立時代と構造上の問題の有無

\section{1 現本堂 (木造)の建立年(10 年毎) と構造上の問題}

1800 年以降に建立した現本堂の建立年を $1801 １ 810$ 年のように 10 年毎で区分すると, 戦後の傾向は 70 年間 (2010 年代 1940 年代) で構造上の問題が徐々に増加したが, 戦前に建立した現本堂の構造 上の問題の割合には大きな変化はみられなかった(図 3 )。

ここで, 建立から 70 年, すなわち築 70 年を超えた段階(戦前/戦後) で構造上の問題が 8 割前後の一定の割合で推移した理由として, 現 本堂の建立時の施工の良否や技術, 大径材の使用, さらには適切な維 持修繥の実施の有無等, 何らかの背景があるものと推察される。ただ し, 建立時の施工の良否や大径材の使用等に関しては個別の寺院に おける実測調査等の検証が必要になる為, 本稿では住職へのアンケ 一ト調查による現本堂の構造上の問題, 維持修繥の実施状況等の関 係について分析する。

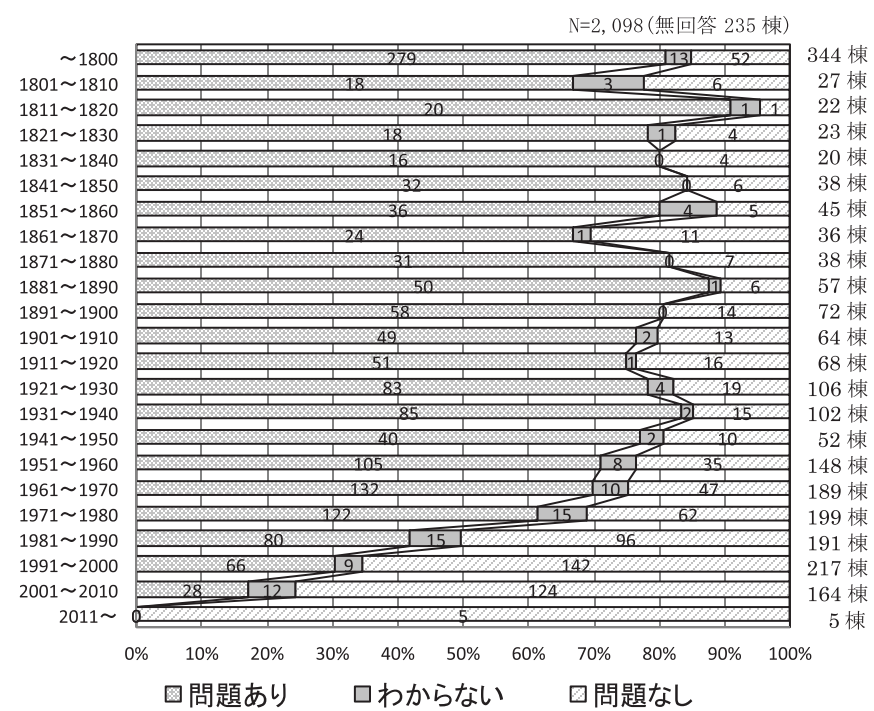

図 3 現本堂 (木造) の建立時代 (10 年毎) と構造上の問題の有無

\section{2 現本堂 (木造)の構造上の問題と今後の使用予定期間}

住職により構造上の問題を認識 (問題有)された現本堂 (木造) は 1, 399 棟 (69\%), 問題を認識されていない(問題無) は 557 棟 (27\%), わ からないは 86 棟 $(4 \%)$ となった。現本堂 (木造)のこれまでの使用期間 の平均は, 問題有が 140 年 ( 0 104), 問題無が 86 年 ( $\sigma$ 98) と 54 年も異 なり, 現本堂の構造上の問題は長期利用の結果とも言える(図 4 )。一 方, 現本堂 (木造) の今後の使用予定期間の平均は, 問題有で 166 年 $(\sigma 184)$, 問題無で 227 年 $(\sigma 180)$ と 60 年も異なり, 今後の長期利用の 為に構造上の問題解決が重要な課題と言える (図 5 )。なお, 建立後 50 年末満の新しい現本堂 200 棟 $(17 \%)$ にて既に構造上の問題が認識 された一方, 建立後 200 年以上の 58 棟 $(12 \%)$ では問題が認識されてい ない事例もあるように, 構造上の問題は建立の新旧に因らない面も ある。ただし, 建立後 200 年以上の現本堂で構造上の問題が認識され ていない場合は, 後世の修理や補強が行われた可能性も考えられる。

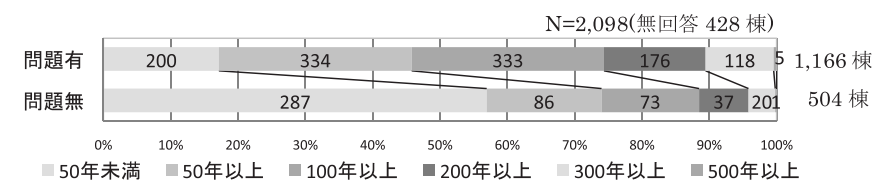

図 4 現本堂 (木造)の構造上の問題とこれまでの使用期間

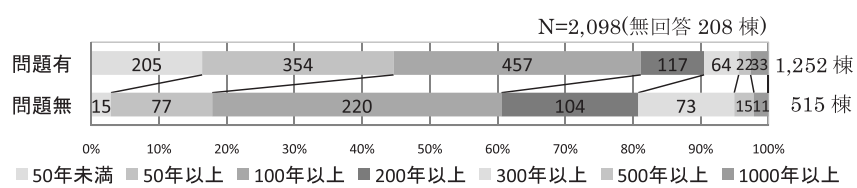

50 年未満 $\square 0$ 年以上 -100 年以上 $\square 200$ 年以上 -300 年以上 -500 年以上 $\square 1000$ 年以上

図 5 現本堂 (木造) の構造上の問題と今後の使用予定期間

現本堂 (木造)の構造上の問題の内訳は, 耐震強度不足が 667 棟 (48\%), 構造材の腐食·老朽化が 613 棟 (44\%), 床材の腐食·老朽化が 444 棟 (32\%), 蟻害が 350 棟 (25\%), 壁材の腐食·老朽化が 327 棟 (23\%) となった。また, その他の 44 棟 (3\%)には, 自然災害の影響 (8 件), 縁 廻り等の腐食 (5 件), 地盤沈下 (5 件) 等があった。ここで, 今後の使用 予定期間を「短期の 50 年末満」と「比較的長期の 200 年以上」注 20) とした現本堂について, 建立した時代別 (江戸以前から明治／戦後) の構造上の問題の内訳は, 今後の使用予定期間を 50 年未満とした寺 院では 200 年以上とした寺院と比べて建立の古い(明治以前) 新しい 
(戦後)に関係なく「耐震強度不足」と「構造材・床材・壁材の腐食・ 老朽化」等の割合がそれぞれ 2〜4 倍と大きな違いを示した(表 6 )。

明治以前に建立した古い現本堂でも今後の使用予定期間を長期と した寺院は構造上の問題の割合が低く,また戦後の建立でも耐震強 度不足や構造材の腐朽の割合が高い本堂もあり,これまでの使用期 間とは関係のない木造の現本堂の計画段階での耐久設計や立地条件 等への配慮も長期利用には重要と考えられる。

表 6 木造本堂の構造上の問題と竣工時代別使用予定期間

\begin{tabular}{|r|c|c|c|c|c|}
\hline & 竣工時代 & \multicolumn{2}{|c|}{ 江戸以前 明治 } & \multicolumn{2}{|c|}{ 戦後 } \\
\cline { 2 - 6 } $\begin{array}{r}\text { 母数使用予定期間 } \\
\text { 356棟 }\end{array}$ & 50 年未満 & 200 年以上 & 50 年未満 & 200 年以上 \\
\hline 数 & $99(100 \%)$ & $88(100 \%)$ & $56(100 \%)$ & $113(100 \%)$ \\
\hline 構造材の度不足食·老朽化 & $54(55 \%)$ & $22(25 \%)$ & $25(45 \%)$ & $14(12 \%)$ \\
\hline 床材の腐食·老朽化 & $42(42 \%)$ & $22(25 \%)$ & $29(52 \%)$ & $4(4 \%)$ \\
\hline 壁材の腐食·老朽化 & $32(32 \%)$ & $12(14 \%)$ & $16(29 \%)$ & $7(6 \%)$ \\
\hline 蟻害 & $35(35 \%)$ & $20(23 \%)$ & $16(29 \%)$ & $2(2 \%)$ \\
\hline その他 & $0(0 \%)$ & $1(1 \%)$ & $0(0 \%)$ & $6(5 \%)$ \\
\hline わからない & $1(1 \%)$ & $1(1 \%)$ & $0(0 \%)$ & $8(7 \%)$ \\
\hline
\end{tabular}

\section{3 現本堂 (木造)の規模と想定使用期間}

本堂の規模が大きくなれば大径材の使用も増え,費用負担等で容 易に建替えはできなくなると推測される。現本堂 (木造)の規模別の 想定使用期間は 100 年以上の利用で規模に応じた長期利用の傾向が みられた (図 6)。また, 平均想定使用年も $50 \mathrm{~m}^{2}$ 末満が 252 年に対し て $350 \mathrm{~m}^{2}$ 以上は 429 年と, 規模の大小で 177 年もの差注 21$)$ となった。

このように, 現本堂 (木造)の想定使用期間は規模も影響している と考えられる。ただし, $300 \mathrm{~m}^{2}$ 以上の比較的大規模な現本堂であって も, 200 年末満の比較的短い想定使用期間があり,これら 41 棟のこれ までの使用期間の平均は 62 年と戦後に建立した新しい本堂が多い。 $\mathrm{N}=2,098$ (無回答 864 棟)

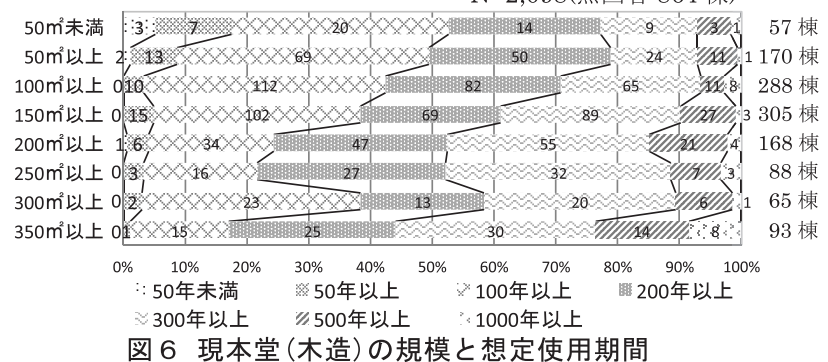

\section{5. 現本堂 (木造)の構造上の問題の要因と維持修繕}

前項では築 70 年を超えた現本堂の構造上の問題が 8 割程の一定 割合となる傾向を確認した。本章以降も引き続き, 木造の現本堂を対 象にして, 現本堂の長期利用に重要となる構造上の問題の要因や屋 根莫替えの有無の関係等を, 補足調査から詳しく検証する。

\section{1 現本堂 (木造)の構造上の問題とその要因}

4.2 では基本調査により, 現本堂 (木造)の構造上の問題が今後の 使用予定期間に影響を与えるものの, 構造上の問題は必ずしも建立 の新旧に因らない面もあることを示した。補足調査では, 現本堂(木 造)の構造上の問題は 401 棟 (55\%) で確認された（図 7 )。

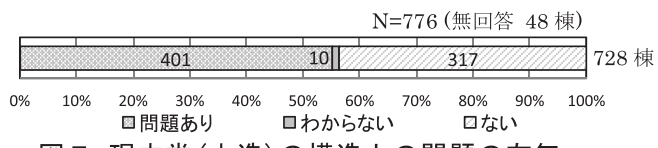

図 7 現本堂 (木造)の構造上の問題の有無
木造本堂の構造上の問題を生じた要因と問題はそれぞれ複数回答 であり,複合的な要因が問題を引き起こしていると考えられる。最も 多い要因として挙げられた経年劣化は, 時間をかけて徐々に影響を 及ぼす為, 放置すれば何れの建物にも一律に起る現象と言える。した がって,「経年劣化」と構造上の問題の関係に特徵はなく,多くで 2 〜4 割となった。一方, 木造本堂の場合は雨水や湿気の影響を受け, 構造材の腐朽や老朽化等につながりやすい特徵がある。「屋根の漏水」 からは屋根材の老朽化が 55 棟 $(82 \%)$, 「湿気が多い」からは床下構 造材の腐朽・老朽化が 44 棟 (54\%)，「床下通気が悪い」からは床下/

表 7 現本堂 (木造)の構造上の問題の要因と構造上の問題

\begin{tabular}{|c|c|c|c|c|c|c|c|c|c|c|c|c|c|}
\hline & & \multicolumn{11}{|c|}{ 棤造上の問題（被数選択） } \\
\hline & & & 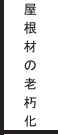 & $\begin{array}{l}\text { 壁 } \\
\text { 材 } \\
\text { の } \\
\text { 免 } \\
\text { 裂 }\end{array}$ & 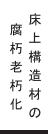 & 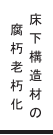 & 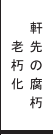 & $\begin{array}{r}\text { 床 } \\
\text { 老林 } \\
\text { 标 } \\
\text { 化度 } \\
\text { 柆 }\end{array}$ & $\begin{array}{l}\text { 壁 } \\
\text { 材 } \\
\text { の } \\
\text { 剥 } \\
\text { 離 }\end{array}$ & 餂 & $\begin{array}{l}\text { 鿬 } \\
\text { 石 } \\
\text { D } \\
\text { 沈 } \\
\text { 下 }\end{array}$ & 蛤 & $\begin{array}{l}z \\
\text { o } \\
\text { 地 }\end{array}$ \\
\hline & & 計 & 146 & 124 & 136 & 132 & 119 & 112 & 89 & 87 & 60 & 18 & 4 \\
\hline \multirow{11}{*}{ 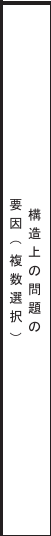 } & 経年出化 & $\begin{array}{c}323 \\
(100 \%) \\
\end{array}$ & \begin{tabular}{|c}
130 \\
$(40 \%)$ \\
\end{tabular} & \begin{tabular}{|c|}
104 \\
$(32 \%)$ \\
\end{tabular} & $\begin{array}{r}123 \\
(38 \%) \\
\end{array}$ & \begin{tabular}{|r|}
119 \\
$(37 \%)$ \\
\end{tabular} & \begin{tabular}{|c|}
109 \\
$(34 \%)$ \\
\end{tabular} & \begin{tabular}{|c|}
103 \\
$(32 \%)$ \\
\end{tabular} & \begin{tabular}{|c|c}
71 \\
$(22 \%)$ \\
\end{tabular} & \begin{tabular}{|c|c}
60 \\
$(19 \%)$ \\
\end{tabular} & \begin{tabular}{|c|}
49 \\
$(15 \%)$ \\
\end{tabular} & $\begin{array}{c}14 \\
(4 \%) \\
\end{array}$ & $\begin{array}{c}4 \\
(1 \%) \\
\end{array}$ \\
\hline & 屋根の漏水 & $\begin{array}{c}67 \\
(100 \%) \\
\end{array}$ & \begin{tabular}{|c|c|}
55 \\
$(82 \%)$ \\
\end{tabular} & \begin{tabular}{|c}
23 \\
$(34 \%)$ \\
\end{tabular} & \begin{tabular}{|c|}
25 \\
$(37 \%)$ \\
\end{tabular} & \begin{tabular}{|l|}
25 \\
$(37 \%)$ \\
\end{tabular} & \begin{tabular}{|c|}
36 \\
$(54 \%)$ \\
\end{tabular} & \begin{tabular}{|c|}
23 \\
$(34 \%)$ \\
\end{tabular} & $\begin{array}{c}22 \\
(33 \%) \\
\end{array}$ & $\begin{array}{c}16 \\
(24 \%) \\
\end{array}$ & \begin{tabular}{|c|}
12 \\
$(18 \%)$
\end{tabular} & \begin{tabular}{c|}
6 \\
$(9 \%)$
\end{tabular} & $\begin{array}{c}0 \\
0 \%) \\
(0 \%)\end{array}$ \\
\hline & 湿氙が多し & 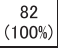 & \begin{tabular}{|c}
33 \\
$(40 \%)$ \\
\end{tabular} & $\begin{array}{c}29 \\
(35 \%) \\
\end{array}$ & $\begin{array}{c}34 \\
(41 \%) \\
\end{array}$ & \begin{tabular}{|c|}
44 \\
$(54 \%)$ \\
\end{tabular} & \begin{tabular}{|c|}
28 \\
$(34 \%)$ \\
\end{tabular} & \begin{tabular}{|c|}
33 \\
$(40 \%)$ \\
\end{tabular} & \begin{tabular}{|c|c}
18 \\
$(22 \%)$ \\
\end{tabular} & \begin{tabular}{|c}
29 \\
$(35 \%)$ \\
\end{tabular} & \begin{tabular}{|c|}
15 \\
$(18 \%)$ \\
\end{tabular} & $\begin{array}{c}8 \\
(10 \%) \\
\end{array}$ & $\begin{array}{c}1 \\
(1 \%)\end{array}$ \\
\hline & 床下通気が覀い & $\begin{array}{c}36 \\
(100 \%) \\
\end{array}$ & \begin{tabular}{|c|}
15 \\
$(42 \%)$ \\
\end{tabular} & \begin{tabular}{|c|}
16 \\
$(44 \%)$ \\
\end{tabular} & \begin{tabular}{|c|}
20 \\
$(56 \%)$ \\
\end{tabular} & \begin{tabular}{|c|}
25 \\
$(69 \%)$ \\
\end{tabular} & \begin{tabular}{|c|}
15 \\
$(42 \%)$ \\
\end{tabular} & \begin{tabular}{|c|}
17 \\
$(47 \%)$ \\
\end{tabular} & $\begin{array}{c}8 \\
(22 \%) \\
\end{array}$ & $\begin{array}{c}13 \\
(36 \%) \\
\end{array}$ & \begin{tabular}{|c|}
10 \\
$(28 \%)$ \\
\end{tabular} & \begin{tabular}{|c|}
1 \\
$(3 \%)$ \\
\end{tabular} & $\begin{array}{c}0 \\
(0 \%) \\
\end{array}$ \\
\hline & 地盤力慙い & \begin{tabular}{|c|}
39 \\
$(100 \%)$ \\
\end{tabular} & \begin{tabular}{|c|c}
17 \\
$(44 \%)$ \\
\end{tabular} & \begin{tabular}{|c|}
14 \\
$(36 \%)$ \\
\end{tabular} & \begin{tabular}{|c|}
17 \\
$(44 \%)$ \\
\end{tabular} & \begin{tabular}{|c|}
22 \\
$(56 \%)$ \\
\end{tabular} & \begin{tabular}{|c|}
15 \\
$(38 \%)$ \\
\end{tabular} & \begin{tabular}{|c|}
16 \\
$(41 \%)$ \\
\end{tabular} & \begin{tabular}{|c|}
11 \\
$(28 \%)$ \\
\end{tabular} & \begin{tabular}{|c|c|}
13 \\
$(33 \%)$ \\
\end{tabular} & \begin{tabular}{|c|}
23 \\
$(59 \%)$ \\
\end{tabular} & \begin{tabular}{|c|}
3 \\
$(8 \%)$ \\
\end{tabular} & $\begin{array}{c}0 \\
(0 \%) \\
\end{array}$ \\
\hline & 蟠害 & $\begin{array}{c}54 \\
(100 \%) \\
\end{array}$ & \begin{tabular}{|c|c}
19 \\
$(35 \%)$
\end{tabular} & \begin{tabular}{|c|c|}
15 \\
$(28 \%)$ \\
\end{tabular} & \begin{tabular}{|c|}
22 \\
$(41 \%)$ \\
\end{tabular} & \begin{tabular}{|c|}
20 \\
$(37 \%)$ \\
\end{tabular} & \begin{tabular}{|c|}
13 \\
$(24 \%)$ \\
\end{tabular} & \begin{tabular}{|c|}
14 \\
$(26 \%)$ \\
\end{tabular} & \begin{tabular}{|c|}
13 \\
$(24 \%)$ \\
\end{tabular} & \begin{tabular}{|c|}
50 \\
$(93 \%)$ \\
\end{tabular} & $\begin{array}{c}7 \\
(13 \%) \\
\end{array}$ & \begin{tabular}{|c|}
4 \\
$(7 \%)$ \\
\end{tabular} & $\begin{array}{c}1 \\
(2 \%) \\
\end{array}$ \\
\hline & 虫害 & $\begin{array}{c}19 \\
(100 \%) \\
\end{array}$ & \begin{tabular}{|c|c}
10 \\
$(53 \%)$
\end{tabular} & \begin{tabular}{|c|}
5 \\
$(26 \%)$ \\
\end{tabular} & $\begin{array}{c}4 \\
(21 \%)\end{array}$ & $\begin{array}{c}8 \\
(42 \%) \\
\end{array}$ & \begin{tabular}{|c|}
6 \\
$(32 \%)$ \\
\end{tabular} & \begin{tabular}{|c|}
6 \\
$(32 \%)$ \\
\end{tabular} & \begin{tabular}{|c|}
2 \\
$(11 \%)$ \\
\end{tabular} & 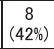 & $\begin{array}{c}2 \\
(11 \%) \\
\end{array}$ & $\begin{array}{c}9 \\
(47 \%)\end{array}$ & $\begin{array}{c}0 \\
(0 \%)\end{array}$ \\
\hline & 施 & \begin{tabular}{|c|c}
14 \\
$(100 \%)$ \\
\end{tabular} & \begin{tabular}{|c|c}
4 \\
$(29 \%)$ \\
\end{tabular} & \begin{tabular}{|c|}
3 \\
$(21 \%)$ \\
\end{tabular} & \begin{tabular}{|c|}
6 \\
$(43 \%)$ \\
\end{tabular} & \begin{tabular}{|c|c|}
5 \\
$(36 \%)$ \\
\end{tabular} & \begin{tabular}{|c|}
5 \\
$(36 \%)$ \\
\end{tabular} & \begin{tabular}{|c|c}
4 \\
$(29 \%)$ \\
\end{tabular} & \begin{tabular}{|c|c|}
5 \\
$(36 \%)$ \\
\end{tabular} & \begin{tabular}{|c|c}
4 \\
$(29 \%)$ \\
\end{tabular} & \begin{tabular}{|c|c}
4 \\
$(29 \%)$ \\
\end{tabular} & $\begin{array}{c}1 \\
(7 \%) \\
\end{array}$ & $\begin{array}{c}0 \\
(0 \%) \\
\end{array}$ \\
\hline & 災害 & $\begin{array}{c}57 \\
(100 \%) \\
\end{array}$ & \begin{tabular}{|c}
16 \\
$(28 \%)$ \\
\end{tabular} & $\begin{array}{c}33 \\
(58 \%) \\
\end{array}$ & $\begin{array}{c}14 \\
(25 \%) \\
\end{array}$ & $\begin{array}{c}19 \\
(33 \%) \\
\end{array}$ & \begin{tabular}{|c|c}
12 \\
$(21 \%)$ \\
\end{tabular} & \begin{tabular}{|c|}
15 \\
$(26 \%)$ \\
\end{tabular} & \begin{tabular}{|c|}
25 \\
$(44 \%)$ \\
\end{tabular} & \begin{tabular}{|c}
11 \\
$(19 \%)$ \\
\end{tabular} & $\begin{array}{c}6 \\
(11 \%) \\
\end{array}$ & $\begin{array}{c}0 \\
(0 \%)\end{array}$ & $\begin{array}{c}0 \\
(0 \%)\end{array}$ \\
\hline & その他 & \begin{tabular}{c|c}
4 \\
$(100 \%)$ \\
\end{tabular} & \begin{tabular}{|c}
2 \\
$(50 \%)$
\end{tabular} & $\begin{array}{c}2 \\
(50 \%)\end{array}$ & $\begin{array}{c}1 \\
(25 \%)\end{array}$ & $\begin{array}{c}2 \\
(50 \%) \\
\end{array}$ & \begin{tabular}{|c|}
1 \\
$(25 \%)$ \\
\end{tabular} & $\begin{array}{c}2 \\
(50 \%) \\
\end{array}$ & $\begin{array}{c}1 \\
(25 \%) \\
\end{array}$ & $\begin{array}{c}0 \\
(0 \%)\end{array}$ & $\begin{array}{c}2 \\
(50 \%) \\
\end{array}$ & $\begin{array}{c}0 \\
(0 \%)\end{array}$ & $\begin{array}{c}0 \\
(0 \%)\end{array}$ \\
\hline & わからない & \begin{tabular}{|c|}
6 \\
$(100 \%)$ \\
\end{tabular} & $\begin{array}{c}0 \\
(0 \%)\end{array}$ & \begin{tabular}{|c|}
0 \\
$(0 \%)$
\end{tabular} & $\begin{array}{c}0 \\
(0 \%) \\
(0 \%)\end{array}$ & $\begin{array}{c}0 \\
(0 \%) \\
\end{array}$ & \begin{tabular}{|c|}
0 \\
$(0 \%)$ \\
\end{tabular} & \begin{tabular}{|c|}
0 \\
$(0 \%)$ \\
\end{tabular} & $\begin{array}{c}0 \\
(0 \%) \\
\end{array}$ & $\begin{array}{c}0 \\
(0 \%) \\
\end{array}$ & $\begin{array}{c}0 \\
(0 \%) \\
\end{array}$ & $\begin{array}{c}0 \\
0 \%) \\
(0 \%)\end{array}$ & $\begin{array}{c}0 \\
(0 \%)\end{array}$ \\
\hline
\end{tabular}

床上構造材の腐朽・老朽化が 25 棟 $/ 20$ 棟 $(69 \% / 56 \%)$ ，「地盤が悪い」 からは礎石の沈下が 23 棟(59\%)，「災害」からは壁材の亀裂が 33 棟 $(58 \%)$ 等のように, 木造本堂特有の構造上の問題の要因も確認で きた(表 7 )。このことから, 構造上の問題の要因を未然に防ぐこと, すなわち, 湿気や地盤等の立地条件を踏まえた建築計画を再検証し, 屋根の経年劣化や漏水を確認する定期的な維持修繒 (屋根莫き材別 の修理周期と下地の確認) 等, 木造本堂に想定される構造上の問題の 要因を人為的に取除くことが現本堂の安全性と健全性を維持するこ とに繋がると考えられる。また, 同様に長期利用を期待する木造本堂 を新たに計画する上でも,これらは重要な要素と指摘できる。

\section{2 現本堂 (木造) の屋根莫替え}

本堂の長期利用には維持修繥が前提となる。特に, 木造本堂の場 合は適切な時期と方法の選択が重要であり, 突発的な災害を除き, 周

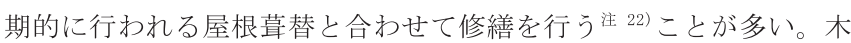
造の現本堂の屋根莫替は 544 棟 $(74 \%$ ) で実施されていた(図 8 )。



伊原によると注 ${ }^{23)}$, 古建築の屋根材の莫替え周期は茅莫き等の自 然莫きは気候等にもよるが平均で 25 年, 瓦や銅鈑莫きは平均 70 年前 後と指摘しているように, 屋根の莫替周期は莫材等でも異なる。屋 根葺き材全体のこれまでの平均使用年数は, 屋根を葺替えた本堂は 
153 年 ( $\sigma$ 105), 莫替え未実施の本堂は 36.5 年 ( $\sigma 46)$ であった。

現本堂の屋根の莫替え理由は雨漏り 289 棟 (53\%), 長期利用の為 283 棟 (52\%), 安全性の確保 134 棟 (25\%) 等の実用的な理由が多く, 見栄えを良くする 36 棟 (7\%) 等は少数であった(図 9)。建立した時

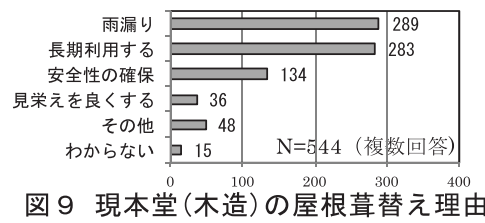

代別の莫替理由として雨漏りは, 江戸以前, 明治, 大正から戦前と $50 \%$ 代で推移しているのに対し, 戦後は 33 棟 (34\%) と低い(表 8 )。こ れは, 江戸以前を含め戦前は雨漏りの度に屋根修理が行われてきた ことを示唆している。一方, 安全性の確保は, 戦後が 28 棟 (29\%) と多 く, 何れの建立時代も長期利用を理由に屋根の莫替を行う寺院が 5 割程となり, 長期利用の為に屋根草替の重要性が認識されていた。

表 8 現本堂 (木造) の屋根葺替え理由と竣工時代

\begin{tabular}{|c|c|c|c|c|c|c|}
\hline & & \multicolumn{4}{|c|}{ 竣工時代 } \\
\hline & & & 江戸以前 & 明治 & 大正から戦前 & 戦後 \\
\hline \multicolumn{2}{|c|}{ 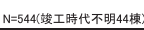 } & $500(100 \%)$ & $219(100 \%)$ & $92(100 \%)$ & $91(100 \%)$ & $98(100 \%)$ \\
\hline \multirow{5}{*}{  } & 雨漏り & $256(51 \%)$ & $123(56 \%)$ & $47(51 \%)$ & $53(58 \%)$ & $33(34 \%)$ \\
\hline & 長期利用する & $250(50 \%)$ & $113(52 \%)$ & $49(53 \%)$ & $43(47 \%)$ & $45(46 \%)$ \\
\hline & 安全性の磼保 & $122(24 \%)$ & $53(24 \%)$ & $24(26 \%)$ & $17(19 \%)$ & $28(29 \%)$ \\
\hline & $\begin{array}{c}\begin{array}{c}\text { 見栄え } \\
\text { を良くする }\end{array} \\
\end{array}$ & $35(7 \%)$ & $19(9 \%)$ & $4(4 \%)$ & $3(3 \%)$ & $9(9 \%)$ \\
\hline & zの他 & $43(9 \%)$ & $16(7 \%)$ & $9(10 \%)$ & $6(7 \%)$ & $12(12 \%)$ \\
\hline
\end{tabular}

\section{6. 現本堂 (木造)の長期利用に求められる災害対策の実態}

過去に災害を経験した現本堂 (木造)が 405 棟 (57\%), 経験無が 308 棟 $(43 \%)$ と, 半数以上で災害を経験していた。具体的な災害は地震 186 棟 (46\%), 台風・豪雨 114 棟 $(28 \%)$, 火災 98 棟 $(24 \%)$, 雪害 28 棟 $(7 \%)$, 戦災・空襲 15 棟 (4\%), 落雷 14 棟 $(4 \%)$, 土砂災害 13 棟 $(3 \%)$, 風害・津波・高潮 (各 1 棟) となった。本章では, 現本堂の災害経験 や災害対策等が長期利用に与える影響を補足調查から検証する。

\section{1 現本堂 (木造)の災害経験と被害}

突発的な大災害による木造本堂の被害は, 壁の亀裂・剥落が 128 棟 $(39 \%)$, 屋根や瓦の落下が 107 棟 $(26 \%)$, 建替えを必要と寸る状態 が 57 棟 (14\%), 建物全体の傾斜が 51 棟 (13\%), 柱の傾斜が 45 棟 (11\%), 補修を行えば旧状を保存しうる状態が 34 棟 (8\%), 基礎の亀 裂が 18 棟 (4\%), 天井の落下が 17 棟 (4\%), 地盤の斜面崩壊や液状化

表 9 現本堂(木造)の災害経験と災害による被害

\begin{tabular}{|c|c|c|c|c|c|c|c|c|c|c|c|c|c|}
\hline & & \multicolumn{11}{|c|}{ 災害被害(複数選択) } \\
\hline & & & $\begin{array}{l}\text { 壁 } \\
\text { の } \\
\text { 亀 } \\
\text { 裂 } \\
\text { や } \\
\text { 录落 }\end{array}$ & $\begin{array}{l}\text { 屋 } \\
\text { 根 } \\
\text { や } \\
\text { 瓦 } \\
\text { の } \\
\text { 落 } \\
\text { 下 }\end{array}$ & $\begin{array}{l}\text { 天 } \\
\text { 井 } \\
\text { の } \\
\text { 落 } \\
\text { 下 }\end{array}$ & $\begin{array}{l}\text { 柱 } \\
\text { の } \\
\text { 傾 } \\
\text { 斜 }\end{array}$ & $\begin{array}{l}\text { 基 } \\
\text { 礎 } \\
\text { 龟 } \\
\text { 裂 }\end{array}$ & $\begin{array}{r}\text { 建 } \\
\text { 物 } \\
\text { 全 } \\
\text { 傾体 } \\
\text { 斜と } \\
\text { し } \\
\text { の } \\
\text { の }\end{array}$ & 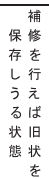 & \begin{tabular}{|r} 
建 \\
$\tau$ \\
す替 \\
る元 \\
状を \\
態必 \\
要 \\
と
\end{tabular} & $\begin{array}{r}\text { 地 } \\
\text { 盤 } \\
\text { 液 } \\
\text { 斜 } \\
\text { 化面 } \\
\text { 崩 } \\
\text { 罢 } \\
\text { や }\end{array}$ & $\begin{array}{l}z \\
\text { क } \\
\text { 他 }\end{array}$ & $\begin{array}{l}\text { か } \\
\text { b } \\
\text { な } \\
\text { い. }\end{array}$ \\
\hline \multirow{8}{*}{\begin{tabular}{|l} 
災 \\
害 \\
経 \\
験 \\
複 \\
数 \\
選 \\
択
\end{tabular}} & 単位(梾) & 計 & 128 & 107 & 17 & 45 & 18 & 51 & 34 & 57 & 7 & 14 & 23 \\
\hline & 地 & $\begin{array}{c}240 \\
(100 \%)\end{array}$ & $\begin{array}{c}101 \\
(42 \%) \\
\end{array}$ & $\begin{array}{c}45 \\
(19 \%)\end{array}$ & $\begin{array}{r}11 \\
(5 \%) \\
\end{array}$ & \begin{tabular}{|c|}
29 \\
$(12 \%)$ \\
\end{tabular} & $\begin{array}{c}14 \\
(6 \%) \\
\end{array}$ & \begin{tabular}{|c|}
33 \\
$(14 \%)$ \\
\end{tabular} & $\begin{array}{c}20 \\
(8 \%)\end{array}$ & \begin{tabular}{|c|}
22 \\
$(9 \%)$ \\
\end{tabular} & $\begin{array}{c}6 \\
(3 \%) \\
\end{array}$ & $\begin{array}{c}4 \\
(2 \%) \\
\end{array}$ & $\begin{array}{c}11 \\
(5 \%)\end{array}$ \\
\hline & 台風、豪雨 & $\begin{array}{c}138 \\
(100 \%)\end{array}$ & 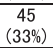 & $\begin{array}{c}65 \\
(47 \%)\end{array}$ & $\begin{array}{c}6 \\
(4 \%)\end{array}$ & $\begin{array}{c}18 \\
(13 \%) \\
(13 \%)\end{array}$ & $\begin{array}{c}5 \\
(4 \%) \\
\end{array}$ & \begin{tabular}{|c|c}
16 \\
$(12 \%)$ \\
\end{tabular} & $\begin{array}{c}16 \\
(12 \%)\end{array}$ & $\begin{array}{c}6 \\
(4 \%) \\
\end{array}$ & $\begin{array}{c}1 \\
(1 \%)\end{array}$ & $\begin{array}{c}9 \\
(7 \%) \\
\end{array}$ & $\begin{array}{c}5 \\
(4 \%)\end{array}$ \\
\hline & 火災 & $\begin{array}{c}118 \\
(100 \%)\end{array}$ & $\begin{array}{c}12 \\
(10 \%)\end{array}$ & $\begin{array}{c}10 \\
(8 \%)\end{array}$ & $\begin{array}{c}2 \\
(2 \%)\end{array}$ & $\begin{array}{c}6 \\
(5 \%)\end{array}$ & $\begin{array}{c}1 \\
(1 \%)\end{array}$ & $\begin{array}{c}6 \\
(5 \%)\end{array}$ & $\begin{array}{c}2 \\
2 \%)\end{array}$ & \begin{tabular}{|c|}
30 \\
$(25 \%)$ \\
\end{tabular} & $\begin{array}{c}0 \\
(0 \%)\end{array}$ & $\begin{array}{c}0 \\
0 \%\end{array}$ & $\begin{array}{c}5 \\
(4 \%)\end{array}$ \\
\hline & 雪害 & $\begin{array}{c}31 \\
(100 \%)\end{array}$ & $\begin{array}{c}7 \\
(23 \%) \\
\end{array}$ & $\begin{array}{c}14 \\
(45 \%) \\
\end{array}$ & $\begin{array}{c}1 \\
(3 \%) \\
\end{array}$ & $\begin{array}{c}3 \\
(10 \%) \\
\end{array}$ & $\begin{array}{c}1 \\
(3 \%) \\
\end{array}$ & $\begin{array}{c}4 \\
(13 \%) \\
\end{array}$ & $\begin{array}{c}10 \\
(32 \%) \\
\end{array}$ & $\begin{array}{c}1 \\
(3 \%) \\
\end{array}$ & $\begin{array}{c}0 \\
(0 \%)\end{array}$ & $\begin{array}{c}3 \\
(10 \%)\end{array}$ & $\begin{array}{c}0 \\
(0 \%)\end{array}$ \\
\hline & 落雷 & $\begin{array}{c}17 \\
(100 \%)\end{array}$ & $\begin{array}{c}6 \\
(35 \%) \\
\end{array}$ & $\begin{array}{c}8 \\
(47 \%)\end{array}$ & $\begin{array}{c}1 \\
(6 \%) \\
\end{array}$ & $\begin{array}{c}2 \\
(12 \%)\end{array}$ & $\begin{array}{c}1 \\
(6 \%)\end{array}$ & $\begin{array}{c}2 \\
(12 \%)\end{array}$ & $\begin{array}{c}2 \\
(12 \%)\end{array}$ & $\begin{array}{c}1 \\
(6 \%) \\
\end{array}$ & $\begin{array}{c}1 \\
(6 \%)\end{array}$ & $\begin{array}{c}1 \\
(6 \%)\end{array}$ & $\begin{array}{c}2 \\
(12 \%)\end{array}$ \\
\hline & 土砂災害 & $\begin{array}{c}16 \\
(100 \%)\end{array}$ & $\begin{array}{c}1 \\
(6 \%)\end{array}$ & 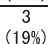 & 11 & $\begin{array}{c}2 \\
(13 \%) \\
\end{array}$ & $\begin{array}{c}1 \\
(6 \%)\end{array}$ & $\begin{array}{c}3 \\
(19 \%) \\
\end{array}$ & $\begin{array}{c}0 \\
0 \%\end{array}$ & $\begin{array}{c}5 \\
(31 \%) \\
\end{array}$ & $\begin{array}{c}1 \\
(6 \%)\end{array}$ & $\begin{array}{c}1 \\
(6 \%)\end{array}$ & $\begin{array}{c}1 \\
(6 \%)\end{array}$ \\
\hline & その他 & $\begin{array}{c}37 \\
(100 \%)\end{array}$ & $\begin{array}{c}6 \\
(16 \%)\end{array}$ & $\begin{array}{c}4 \\
(11 \%)\end{array}$ & $\begin{array}{c}2 \\
(5 \%) \\
(5 \%)\end{array}$ & $\begin{array}{c}5 \\
(14 \%)\end{array}$ & $\begin{array}{c}1 \\
(3 \%)\end{array}$ & $\begin{array}{c}1 \\
(3 \%)\end{array}$ & $\begin{array}{c}2 \\
(5 \%)\end{array}$ & $\begin{array}{c}5 \\
(14 \%) \\
(14 \%)\end{array}$ & $\begin{array}{c}0 \\
(0 \%)\end{array}$ & $\begin{array}{c}0 \\
(0 \%)\end{array}$ & $\begin{array}{c}1 \\
(3 \%)\end{array}$ \\
\hline
\end{tabular}

が 7 棟 $(2 \%)$, その他は建物の部分破損 6 棟, 雨漏り・浸水 6 棟, 仏具 等の物品破損 2 棟であった。なお, 災害と被害は各々複数回答であり, 複合的な災害経験が被害に関係する場合もあるが, 災害別の特徵も みられた。災害別の被害は地震では壁の亀裂・剥離が 101 棟(42\%)， 台風・豪雨では屋根や瓦の落下が 65 棟 (47\%), 火災では建替えを必 要と寸る状態が 30 棟 (25\%), 雪害では屋根や瓦の落下が 14 棟 (45\%), 落雷では屋根や瓦の落下が 8 棟 $(47 \%)$, 土砂災害では建替えを必要 とする状態が 5 棟 (31\%) とそれぞれ最も多い(表 9$)$ 。

地震や台風・豪雨の場合は壁の亀裂・剥離, 屋根や瓦の落下等の 部分的な被害が多い一方, 柱や建物全体の傾斜等は根本修理に繋が る災害も 1 割程でみられ, 火災や土砂災害も建替えに繋がる被害の 割合が約 3 割と高い。このように, 災害種別で木造本堂へ与える被 害に特徵があり, 地震や台風・豪雨の場合は根本修理に, 火災や土砂 災害の場合は建替え等の甚大な被害に繋がる事例がみられた。

\section{2 現本堂 (木造)の災害経験と災害 (地震) 対策}

前項で示したように, 最も多くの現本堂 (木造) が経験した災害が 地震であり, 突発的な被害は現本堂の長期利用にも直接的な影響を 与える。複合的な災害が被害に影響を及ぼす事例もあるが, 地震の場 合は被害に特徴がある。また, 老朽化した木造の寺社建築が地震で倒 壊する報道を受け安全意識が高まり, 地震対策を行う寺院もある。

これまでに災害対策を実施した木造の現本堂は 251 棟 (36\%), 実 施していない現本堂は 411 棟(59\%) あった(図 10)。

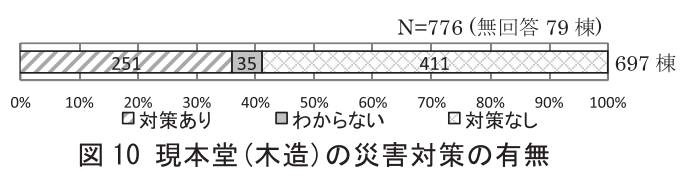

また, 地震等の災害で被害を経験した現本堂(木造)では 159 棟 (42\%)で対策が行われ，災害経験のない現本堂の 73 棟 (26\%)より高 い割合であった(図 11)。このように, 災害経験が災害対策に結びつ いたとも言える。しかし，災害を経験しながらも災害対策を未実施の 寺院も半数以上あり, これらは何らかの応急処置で対応したか, 傷ん だ箇所だけ部分的に修理したものと考えられる。

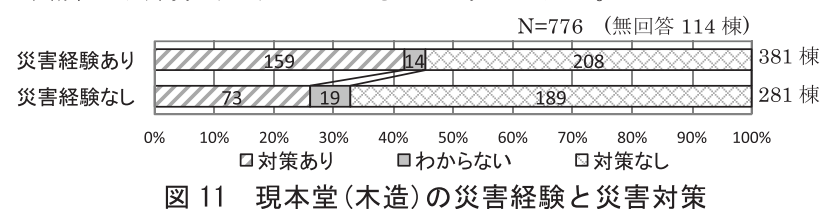

災害対策の内容は柱・梁の補強 94 棟 (37\%), 而震診断60 棟 (26\%), 地盤の補強 53 棟 (21\%), 鉄筋ブレース・筋交 51 棟 (20\%), 壁の新設 50 棟 $(20 \%)$, 屋根莫材の軽量化 43 棟 (17\%), 面格子補強 33 棟 $(13 \%)$, ダンパー 12 棟 $(5 \%)$, その他 53 棟 (21\%) となり, その他は「新基準で 建築」 22 棟や「基礎・壁・金物等の部分補強」 21 棟等であった。

なお，耐震診断を実施した 60 棟の中で診断のみが 24 棟 $(40 \%)$ と補 強を未実施の寺院も多い。診断のみ実施した寺院では診断の結果, 対策が不要と判断したか, 建替えの時期を早めた等の理由が考えら

表 10 現本堂 (木造) の耐震診断と災害対策

\begin{tabular}{|c|c|c|c|c|c|c|c|c|c|c|}
\hline \multirow{2}{*}{\multicolumn{2}{|c|}{ 単位(楝) }} & \multicolumn{9}{|c|}{ 災害対策(複数回答) } \\
\hline & & $\begin{array}{l}\text { 診断 } \\
\text { のみ }\end{array}$ & $\begin{array}{c}\text { 柱梁の } \\
\text { 補強 }\end{array}$ & $\begin{array}{c}\text { 地盤の } \\
\text { 補強 }\end{array}$ & 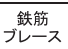 & $\begin{array}{l}\text { 壁の } \\
\text { 新設 }\end{array}$ & $\begin{array}{c}\text { 面格子 } \\
\text { 補强 }\end{array}$ & $\begin{array}{l}\text {. 屋根蓄材 } \\
\text { 軽量化 }\end{array}$ & ダンパー & その他 \\
\hline 耐震診断 & $\begin{array}{c}60 \\
(100 \%)\end{array}$ & $\begin{array}{c}24 \\
(40 \%)\end{array}$ & $\begin{array}{c}19 \\
(32 \%) \\
(32 \%\end{array}$ & $\begin{array}{c}9 \\
(15 \%)\end{array}$ & $\begin{array}{c}10 \\
(17 \%)\end{array}$ & $\begin{array}{c}19 \\
(32 \%)\end{array}$ & $\begin{array}{c}6 \\
(10 \%)\end{array}$ & $\begin{array}{c}4 \\
(7 \%)\end{array}$ & $\begin{array}{c}7 \\
(12 \%)\end{array}$ & $\begin{array}{c}7 \\
(12 \%)\end{array}$ \\
\hline
\end{tabular}


れる(表 10)。また, 実施した対策として壁の新設 19 棟(32\%)や柱・ 梁の補強 24 棟 (32\%) を行う寺院が比較的多かった。次に, 現本堂に 災害対策を実施した動機は, 将来の地震一の予防 125 棟 $(66 \%)$, 地震 を経験 51 棟 (27\%), 将来の台風・豪雨への予防 29 棟 (15\%), 台風・ 豪雨を経験 24 棟 $(13 \%)$, その他 32 棟 (17\%) であった。ここで, 災害 経験はないものの現本堂に災害対策を実施した 88 棟の中で 73 棟 (83\%) は将来の地震への予防または, 台風・豪雨への予防であり, 災害 経験よりも将来への予防が主な動機となっていた。しかし, 寺院全体 としては現本堂の災害対策の実施率 251 棟 $(36 \%)$ は決して高くなく, 実施率の向上は今後の課題と言える。

一方, 災害対策を実施しない木造の現本堂は図 10 で示した様に 697 棟中 411 棟 (59\%) あり, 戦前が 453 棟中 258 棟 (57\%), 戦後が 250 棟中 116 棟 $(46 \%)$, 時代不明 37 棟 (51\%) と戦前の現本堂で高い割合を 示した(表 11)。災害対策を実施しない理由には, これまでの災害経 験を通じて問題を認識していない現本堂が最も多く 162 棟 (39\%) あ りここのうち戦前の建立が 101 棟 (22\%), 戦後は50棟 $(20 \%)$ とほぼ同じ 割合であった。戦後建立の現本堂は築年数が浅い分だけ災害に遭遇 する確立も低いが, 建築基準法等により構造安全性が担保された面 も考えられる。一方, 戦前に建立した現本堂の場合は建立時の施工精 度等, 職人技術の良否も関係しているものと考えられる。

表 11 災害対策を実施しない理由と現本堂の建立時代 (戦前/戦後)

\begin{tabular}{|c|c|c|c|c|}
\hline & \multirow{3}{*}{ 全体 } & \multicolumn{3}{|c|}{ 建立時代 } \\
\hline & & 戰前 & 戦後 & \begin{tabular}{|l} 
時代不明 \\
\end{tabular} \\
\hline & & 453 棟(100\%) & 250 棟(100\%) & 73 棟(100\%) \\
\hline 災害対策を実施しない & 411 棟 & $258(57 \%)$ & $116(46 \%)$ & 37 棟 $(51 \%)$ \\
\hline 災害経験を通じて問題を感じない & 162棟 & $101(22 \%)$ & $50(20 \%)$ & 11 棟 $(15 \%)$ \\
\hline 修理費用が不明 & 147 棟 & $101(22 \%)$ & $31(12 \%)$ & 15棟 $(21 \%)$ \\
\hline
\end{tabular}

次に多い「修理費用が不明」は 147 棟 (36\%) あり, 戦後が 31 棟 (12\%) に対し戦前が 101 棟 $(22 \%)$ と戦前建立の現本堂で高い割合であった。 戦前建立の現本堂の場合は伝統木造で建てられた本堂の構造を理解 する堂宮大工が近畿地方等, 一部の地域を除き不足したこと等も影 響し, 修理費用が不明で対策がなされていない可能性も考えられる。

\section{3 現本堂 (木造)の構造上の問題と災害 (地震) 対策}

木造の現本堂の災害経験の要因を,構造上の問題から明らかにす る。図 11 で示したように, 災害経験がある木造の現本堂では 159 棟 $(42 \%)$ で災害 (地震) 対策が行われ, 災害経験のない現本堂 73 棟 (26\%)より高い割合であった。災害後に対策を実施したかは未確認 であるが, 現本堂の災害経験が災害対策を行うきっかけとなった面 が窺える。次に, 災害を経験した木造の現本堂を戦前と戦後の建立に 分け, 構造上の問題と災害対策の実施の有無をそれぞれ比較すると, 戦前建立で構造上の問題のない現本堂では 9 棟 (75\%)で災害対策が 行われ, 構造上の問題のある現本堂の 45 棟(43\%)より高い割合とな った(図 12)。

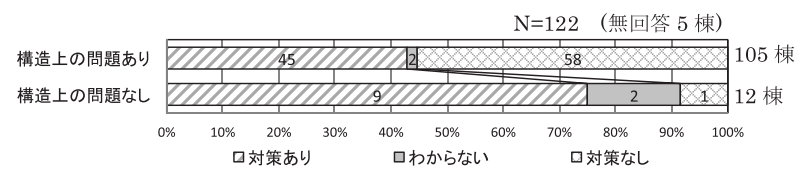

図 12 現本堂の構造上の問題と災害対策 (災害被害有/戦前建立)

一方, 戦後建立で構造上の問題がない現本堂では 14 棟 (56\%)で災害 対策が行われ, 構造上の問題のある現本堂の 15 棟(50\%) とほぼ同じ 割合となった(図 13)。
$\mathrm{N}=70$ (無回答 15 棟)

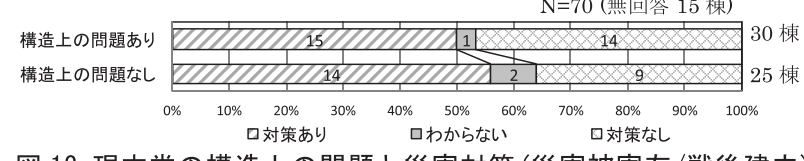

図 13 現本堂の構造上の問題と災害対策 (災害被害有/戦後建立)

このように, 建立後 70 年以上を経過した戦前建立の古い木造本堂 の場合は災害対策を行うことが構造上の問題の軽減に繋がると考え られる。住職が認識した構造上の問題を解決することが全ての災害 による被害を防ぐことにはならないが, 被害を受ける前に予防的に 構造上の問題への対策を実施することが望ましいのは自明である。

その一方で, 災害対策を実施しながらも災害による被害を経験し, 構造上の問題ありとした戦前建立の現本堂も 45 棟 (43\%) 存在した。 災害対策を実施したにも関わらず被害に遭い構造上の問題が判明し た事例とも考えられるが,これらの寺院では耐震診断の実施率が 8 棟 $(18 \%)$ と全体の割合 $(37 \%)$ と比べ半数以下と低いことから, 適切な 対策が行われなかった可能性も考えられる。再度, 耐震診断を実施し た上で必要な災害対策と補強を行うことが重要と言える。

\section{4 現本堂 (木造)の災害対策と相談者}

木造の現本堂の災害 (地震) 対策に関して住職等の寺院関係者が相 談した大工等の職種 (複数回答) を堂宮大工, 建設会社, 一般の大工, 設計者注 24 ) で分類したところ,一般の大工 200 棟 (29\%), 堂宮大工 189 棟 $(28 \%)$, 建設会社 115 棟 (17\%), 設計者 20 棟 (3\%), 相談者不在 156 棟 $(23 \%)$ となった。相談者別の現本堂の災害 (地震) 対策の実施 (有・無) は, 割合の高い順に堂宮大工等 97 棟 (51\%), 設計者 9 棟 $(45 \%)$, 建設会社 74 棟 (41\%),一般の大工 81 棟 (32\%), 相談者不在 25 棟 (16\%) となり, 職種別で現本堂の災害 (地震) 対策の実施割合が 異なり, 相談者のいない寺院では対策の割合は低かった(図 14)。

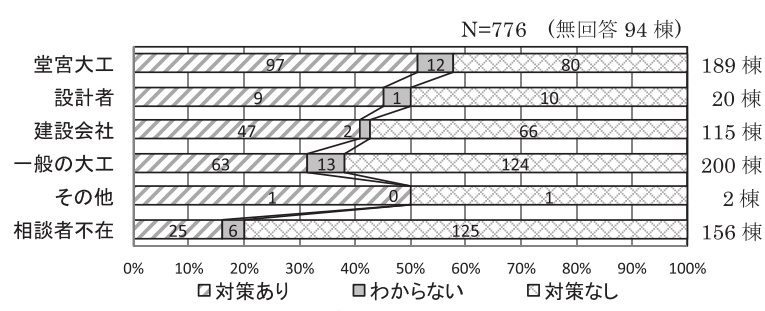

図 14 現本堂 (木造)の災害対策の相談者と対策の有無

相談者別の災害対策の内容は, 堂宮大工, 一般の大工, 建設会社, 設 計者でそれぞれ特徵があり, 堂宮大工の場合は耐震診断を実施した 本堂が 34 棟 $(35 \%)$ と多く,設計者と同様に地盤の補強, 壁の新設, ダ ンパーの利用も比較的多い(表 12)。また, 鉄筋ブレースは堂宮大工, 一般の大工, 建設会社に共通して行われ, 屋根莫材の軽量化や面格子

表 12 現本堂 (木造)の災害対策の相談者と災害対策の内容

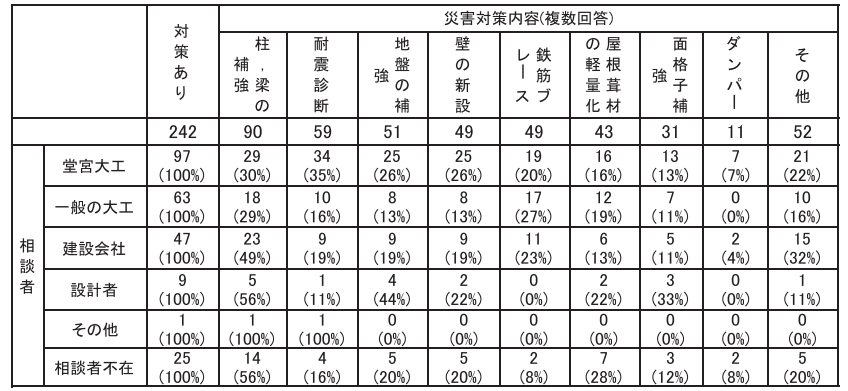


補強では設計者も含まれる。なお, 柱・梁の補強は何れの相談者でも 行われるが, 特に建設会社と設計者に多く一般の大工の場合は他の 職種に比心゙, 何れの項目も全般的に少ない。図 14 で示したように, 一般の大工は相談者の中でも災害対策を実施する割合も低く, 対策 の内容も堂宮大工と比べ限られていた。

また, 戦前と戦後の建立で分けると, 戦前建立の現本堂の災害対策 の相談者は一般の大工が 55 棟と多く, 戦後の建立では建設会社が多 い等の特徴があった (図 15)。木造伝統構法による古い本堂への災害 対策の相談を堂宮大工が多く関わるものと推測したが, 実際には堂 宮大工に依頼できない寺院や地域も多く, 一般の大工や建設会社が

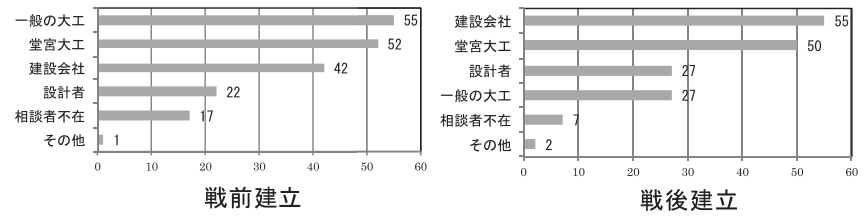

図 15 木造本堂 (戦前建立/戦後建立)の災害対策の相談者

現本堂の災害対策の相談を受け, 同時に必要に応じて修理を実施し ているものと考えられる。またこれが, 戦前に建立した古い現本堂の 災害対策における我が国の現状である。

\section{7.おわりに}

\section{1 まとめ}

建物種別, 構造上の問題の要因, 維持修繥, 災害対策と相談者等, 現 本堂の長期利用に与える影響に関して下記が明らかになった。

(1) 現本堂の建物種別と使用期間

3 種類の建物種別で比較すると, 現本堂の想定使用期間は A. 地域 文化財にて長期の傾向がみられたが, 構造上の問題は建築種別に関 係なく認識された。これは, 古い本堂の多い A. 地域文化財だけでな く, B. 非建替え型や C. その他であっても構造上の問題が一様に認識 されたと言え, 同時に修理を繰り返すことで何れの建物種別も構造 上の問題は解決され, 長期利用に繋がることを示唆している。

(2) 現本堂 (木造)の構造上の問題等と使用期間

2010 年代から 1940 年建立の 70 年間で現本堂 (木造)の構造上の問 題を認識する割合が徐々に増加し, 戦前に建立した現本堂の構造上 の問題を認識する割合はその後, 江戸時代の建立を含め 8 割程で変 化はなかった。現本堂の構造上の問題は長期利用の結果とも言える 一方, 今後の使用予定期間は, 問題有と問題無で 60 年も異なり, 今後 の長期利用の為に構造上の問題解決が課題と言える。

(3) 現本堂 (木造)の構造上の問題の要因と維持修繥

現本堂 (木造)には,屋根材や構造材の老朽化等がある。また,構造 上の問題の要因として経年劣化, 漏水, 湿気, 通気, 地盤,蟻害等があり, 多くは複合的な要因が影響している。しかし, 時間をかけて徐々に影 響を及ぼす経年劣化は維持修繥をせずに放置すれば何れの建物にも 一律に起る現象と言える。したがって, 屋根の維持修繥等, 人為的な 問題除去が本堂の長期利用に求められる。

（4）現本堂 (木造)の長期利用に求められる災害対策の実態

現本堂 (木造)が最も多く経験した災害は地震であり,壁の亀裂・ 剥落, 屋根や瓦の落下, 建物全体の傾斜, 柱の傾斜等の被害であった。 災害対策には, 柱・梁の補強, 而震診断, 地盤の補強, 鉄筋ブレース・ 筋交, 壁の新設, 屋根莫材の軽量化, 面格子補強等があり, 耐震診断を
実施した中で診断のみは 4 割であった。災害対策を実施した動機は, 災害経験よりも将来への予防が主であるが, 寺院全体の実施率 $36 \%$ は高くない。また, 現本堂 (木造)の災害対策の相談者は, 堂宮大工, 設計者, 建設会社, 一般の大工であり, 堂宮大工の場合は耐震診断の 実施率が高い。一方,一般の大工の場合は他の職種と比心゙, 何れの災 害対策の項目も少なく, 戦前建立の古い現本堂の災害対策の相談を 最も多く受けるのも一般の大工であった。

\section{2 今後の展望}

本研究は住職へのアンケート調查を基本としており,堂宮大工や 一般の大工等による現本堂の改修事例の具体的な検証は行っていな い。今後, 複数の具体的な改修事例を元に, 構造の安全性と文化的価 值の保存を含め改修の有効性を検証することも重要と考えている。

合わせて, 本研究では現本堂の長期利用に与える影響を示したが, 現本堂の長期利用に求められる部位毎の修理周期を仕上別に明らか にすることも, 計画的な修理を行う上で重要な視点と言える。

\section{謝辞}

調査にご協力いただいた全国の仏教寺院の住職の皆様に深く感謝 致します。なお, 本稿は東京都市大学卒業生の駒形祐輔氏, 井田光哉 氏, 岡田拓大氏, 戸田千春氏, 長嶋元春氏, 小泉光希氏の協力を得た。 また, 2009 2010 年度の (財) 鹿島学術振興財団と 2012 2015 年度の 学術研究助成金 (基盤研究 (C)) の助成による研究の一部である。

\section{参考文献}

1）佐々木健, 駒形祐輔, 勝又英明: 国指定文化財を除く寺院本堂の使用期間 とその要因, 日本建築学会計画系論文集, 第 720 号, pp. 323-331, 2016.2

2）佐々木健, 勝又英明: 国指定文化財を除く全国の寺院本堂の建替えの実

態, 日本建築学会計画系論文集, 第 701 号, pp. 1567-1575, 2014.7

3）關野貞:建築史上より見たる古社寺の災害, 建築雑誌 vol. 38 No. 451, pp. 129 137, 1924. 1

4) 加藤邦男: 阪神 - 淡路大震災と歴史的建造物, 思文閣出版, 1998.4

5）内田祥哉: 日本の伝統建築の構法 柔軟性と寿命, 市ヶ谷出版, 2009.10

6）国土交通省近畿地方整備局: 京都を中心とした歷史都市の総合的魅力向 上に係る文化財を地域に活かす支援組織と制度のあり方の実効性調査報 告書, 平成 18 年度国土政策創発調查, 2007.3, http://www. mlit. go. jp/kokudokeikaku/souhatu/h18seika/03kyoto/03 bunka_02honpen1.pdf（参照 2015.7.29）

7）和田章, 他:建築の原点に立ち返る-暮らしの場の再生と革新 東日本大 震災に鑑みて (第二次提言), 建築雑誌 vol. 128 No. 1650, pp. 52 65, 2013. 10

8）町田章, 他：地域文化財の保存修復 考え方と方法 -現状・課題・これから 一, 奈良国立文化財研究所, 2000.3

9）伊原惠司: 正福寺地蔵堂 唐様 (禅宗様) の代表作 規矩術技法の解明, 建築 雑誌 vol. 116 No. 1471, pp. 54 57, 2001. 5

10）光井渉: 地震被害と文化財建造物, 月間文化財 390 号, 第一法規株式会

社, pp. 13 21, 1996. 2

11）腰原幹雄, 藤田香織, 大橋好光, 坂本功: 1923 年関東地震による鎌倉の社寺 の被害, 日本建築学会計画系論文集, 第 573 号, pp. 129-135, 2003. 11

12）宮本俊輔, 宮澤健二, 入江康隆, 後藤治: 寺院建築の耐震診断と耐震改修事 例, 日本建築学会計画系論文集, 第 593 号,pp. 87-94, 2005.7

13）後藤治: 伝統構法木造からみた建築関連法規の課題, 建築・社会システム に関する連続シンポジウムく第 14 回〉伝統構法木造建築物における諸問 題と今後の展望, pp. 11 12, 日本建築学会, 2011.12

14）角陸順香, 清家剛, 藤田香織, 宇野繥晴:木造重要文化財建造物の耐震補強 における意志決定プロセスに関する研究-構造設計者の役割を中心とし て-, 日本建築学会計画系論文集, 第 590 号, pp. 65-72, 2005.4

15）関野克, 伊藤鄭爾: 38. 奈良市在家の構造的耐用年限について, 日本建築學 会研究報告, pp. 315 318, 1950.8

16）これが日本のお寺神社だ!, http://www. otera. co. jp (参照 2007.6. 10, 2008.6.3, 2009.5.20, 2010.5.14, 2011.5.19, 2012.4.26) 
17）文化庁編:宗教年鑑平成 23 年版,ぎょうせい, 2013.9

18）goo 㚈ソページ, http://townpage. goo. ne. jp/(参照 2011. 6.23, 2012.5.31)

19）おてらなび, http://www. otera-navi.com/ (参照 2011. 6.23, 2012.5.31)

20）伊原惠司:古建築の修理周期, 普請研究 32 号古建築の修理周期と普請 帳, 普請研究会, 1990.8

\section{注}

注 1）現本堂の構造上の問題とは, 構造材の腐朽・老朽化, 白蟻の被害, 屋根材 の老朽化, 壁材の老朽化, 床材の老朽化, 耐震強度不足等を示す。なお, アン ケート調査では, 住職が把握している範囲での回答とし, 専門家による診断 を前提としていない。また, 図の「問題有」は構造上の問題を住職が認識し, 「問題無」は問題を認識していないことを示す。さらに, 「現本堂」とは現 在, 使用している本堂, 「前本堂」とは現本堂を建替える前の本堂とする。

注 2）参考文献 3) p. 131 に関東大震災では「市内に於いては其本堂が倒潰し た者は一つもありませぬ。下町に属す者は殆ど総て火災の為め, 鳥有に帰し た」とあり,p.132に「圓融寺の本堂は北に向ひ一尺許り移動し,傾斜しま した。此建物は相當に年代も古く且つ構造も堅牢でなく, 修繕も㤐っていた 訳で倒壊はしなかったが著しく傾斜した」と記載された。また, 参考文献 4)に, 阪神・淡路大震災で尼崎寺町や有馬の寺院の被害の要因として,いず れの建物も維持管理が不十分であったと記された。

注 3) 拙稿, 参考文献 2) の 8. まとめ (3) 本堂への建替え (日本全国) に, 非木造 本堂が 1960 年〜 1970 年代に普及したことが記された。

注 4）参考文献 5)p. 45 に, 伝統的な木造建築を新築する際の実情として, 「世の中の社寺建築は鉄筋コンクリートか鉄骨造で造ることになり,木造は技術 も途絶えていった」とあり, また, 参考文献 6)p. 309 に,「1960年代以降の 一般建築業界の発展によって, 伝統的な建築技能を発揮する分野は甚だ減 少した。伝統的な日本建築の施工実技を体験できる事業場の減少は,技能者 の経験不足とそれに伴う技量の水準低下を招いている。」と記載。1960 年 代以降, 文化財修理以外では木造伝統構法での新築等, 社寺建築に従事する 機会が減少したことが, 技術の衰退に繋がったことが指摘された。

また, 参考文献 6) p. 19(5)補修に係る職人等の確保に関する課題・ニー ズに, 京都府周辺の文化財所有者への調査にて, 文化財を修理・維持管理す る職人等の高齢化と後継者不足により人材確保が困難になり, 回答者の 11. $9 \%$ が文化財保存の課題と記載。文化財をはじめ古い寺社建築の多い京都 周辺の実態だけに, 全国的にはさらに深刻な状況と推測される。

注 5）参考文献 7)p. 16の社) 日本建築学会による第二次提言 (提言 65)に,「被 災した歴史的建築物を継承するためには補強や改良をしなければならない ことも多い。また, 災害による被害を最小にとどめるには日常から補強や改 良に勤しんでおくことも望まれる。とはいえ, 補強や改良が簡便で安価でな ければ所有者等の負担が大きくなってしまい, 多くの歴史的建築物を継承 することは困難である。そのため, 補強や改良を簡便で安価にできる方法を 開発するための調査研究は不可欠である。」と記載。

注 6) 保存を目的とした修理とは参考文献 8)p. 43 に「自治体指定の文化財, 登録文化財, 未指定文化財等, 歴史的な建物が多様に文化財として保存の対 象となっている現在, それに伴う修復も底辺が拡大しつつある」と記載のよ うに, 文化財修理の延長上に予備軍としての非建替え型の保存修理がある。 また, p. $123 に て$, 基本的に建替えのない地域文化財の修理においても「地 元に密着する立場からより木目細やかな維持管理が本当は必要で, これに より根本修理を必要とする事態を招かないことが大切だが, 小額補助への アレルギーがある」と指摘。根本修理が必要になる前に小修理を繰り返す ことが, 所有者負担が前提となる未指定文化財等の古い本堂の修理費を押 さえ, 長く使い続ける為には重要と言える。その一方で, p. 21 に「本来文化 財修理には, かつての状態を示す痕跡の調査や材料の取り替え範网につい て求められるが, 施工上の都合や利害を優先的に考えやすい」とあり, 指定 文化財においても根本修理により文化財の価值を損ねる可能性が指摘され ている。なお, p. 70 に「破損状況に応じた修理の段階として, 1. 経年劣化は 単純な修理, 2. 維持管理を意った場合は管理強化, 3. 建物の元々の欠宿は改 良的な修理」と記載され, 保存修理には経年劣化以外の対応も必要となる。

注 7）現本堂のこれまでの使用期間は建立年から 2013 年までとする。但し, 調査は 2007 年度から 2012 年度にかけて順次実施しており, 中には本堂の建 替えを予定している寺院もあった為, 2013 年時点では既に建替え予定また は工事中の現本堂等も考えられるが, 本研究では建替え未実施として分析 した。

注 8）現本堂の今後の使用予定期間の加算方法は, 50 年末満は 25 年, 50 年以 上は 75 年, 100 年以上は 150 年, 等として計算した。

注 9）参考文献 10) p. 21 に「文化財建造物の本格的な補強や地盤改良は解体
修理を待つしかなく,資金面などの問題から普段の維持や小規模な修理が クローズアップされ, 部材の腐朽防止や破損箇所をこまめに修理すること は建物が本来持っている強度を最大限引き出すことに慗がる」と指摘。

注 10）参考文献 13）に, 現行の建築基準法の下で寺社建築を建てようとする と, 無駄な補強や壁を加えることとなる為, 柱梁による軸組の耐力, 太い柱 の復元力等, 寺社建築の特性に応じた構造計算を法改正によって新たに章 立てすることで順次解決を図る必要性を指摘した。また, 古い建物であれば あるほど基淮法に関わる告示の仕様と異なる可能性が高い為, 現行の告示 に変わる新たな制度として, 地域の棟梁によって永年作り続けられてきた 地域性のある建築の型式認定等の方法で運用する等の改善が提起された。

注 11）参考文献 15) pp. 107〜 108 に, 住宅の木材量と耐用年限との関係では, 柱の径が大きくなるに従い, 耐用年限も増加することが示された。合わせ て,「耐用年限の長い家屋を造るときは却って延べ坪を増大せしめることが できる」とあり,耐用年限と規模の関係も示された。

注 12）参考文献 16）により都道府県別リストを作成した結果, 福島, 徳島, 宮 崎, 沖縄, 北海道は参考文献 17) に記載された寺院数より一割以上少なかっ た。そこで, 福島・徳島・宮崎では参考文献 18) を, 北海道・沖縄では参考文献 19）を併用した結果, 宗教年鑑の寺院数と同等以上となった。このようにし て, 76,849 寺院分のデータベースを作成した。

注 13) 伝統宗教とは, 新興宗教 (宗教の開祖が 1900 年以後, およそ 100 年未 満の宗派とする) を除いた寺院と定義する。

注 14）無作為抽出の抽出率 (\%) は, 調查した年度により, 20〜30\%と異なる (北海道・東北 $30 \%$, 関東 $25 \%$, 中部・近畿・中国・四国・九州 $20 \%$ ) が, 初 年度の東京都は無作為抽出ではなく, 全寺院を対象として事前に電話調査 を実施し, 竣工年と構造を確認し, その後, 予定していた基本アンケート調 査の協力は不可と回答した寺院には,アンケートを送付しないこととした。 注 15）基本調査とは, 地方別に全国の寺院へ行なう一律のアンケート調査で, 約 55 の設問(選択肢と記述式)によるアンケート調査。

注 16）地域文化財 82 棟の中で, 指定文化財の現本堂のうち 1 棟は調査が行わ れた 2008 年の後となる 2013 年 8 月 7 日に国の重要文化財に指定された。 また, 国登録文化財の現本堂のうち 1 棟も基本調査が行われた 2011 年の翌 年, 2012 年 12 月 28 日に国の重要文化財に指定された。ただし, 本稿ではア ンケートの回答時点の指定や登録の状況とした。なお, 国登録文化財は新し い制度であり登録も比較的新しい現本堂も多いが, 全て基本調査の時点で 登録済みであることを確認した。

注 17）拙稿, 参考文献 2)の8. まとめ (5) 本堂の建替えの要件より,修理を繰り 返して本堂を使用し続けることを非建替え型とする。

注 18) 本稿で戦前, 戦後の「戦」とは第二次世界大戦を示す。

注 19）本堂の構造上の問題とは, 構造材の腐朽 - 老朽化, 白蟻の被害, 屋根材 の老朽化, 壁材の老朽化, 床材の老朽化, 耐震強度不足等を示す。なお, アン ケート調査では, 住職が把握している範囲での回答とし, 専門家による診断 を前提としていない。また, 図の「問題有」は構造上の問題を住職が認識し, 「問題無」は問題を認識していないことを示す。

注 20) 本稿では 100 年未満を短期利用, 300 年以上を長期利用として考察して いるが, 表 5 では現本堂の構造上の問題と使用期間の特長がわかりやす い, 50 年末満を短期利用, 200 年以上を長期利用と区分して考察した。

注 21）本堂の規模に応じた平均使用推定年数は, $50 \mathrm{~m}^{2}$ 未満が 252 年, $50 \mathrm{~m}^{2}$ 以 上は 240 年, $100 \mathrm{~m}^{2}$ 以上は 276 年, $150 \mathrm{~m}^{2}$ 以上は 298 年, $200 \mathrm{~m}^{2}$ 以上は 341 年, $250 \mathrm{~m}^{2}$ 以上は 345 年, $300 \mathrm{~m}^{2}$ 以上は 310 年, $350 \mathrm{~m}^{2}$ 以上は 429 年であった。 注 22）参考文献 9), p. 77 に「建物を修復するには修理の程度から, 屋根の莫 替え部分修理, 半解体修理, 全解体修理を決める」と記載。また, 参考文献 1) 5.4 に「本堂の屋根莫替えの際に, 合わせて他の修繥工事を実施した寺 院は $73 \%$, 未実施の寺院は $18 \%$ であった。と記載。指定文化財と違い, 一般 の寺院本堂の修理は周期的に行われる屋根の莫替えと同時に修理が行われ る事例が多い。

注 23）参考文献 20), p. 4 5 に「茅莫き屋根の莫替え周期が平均で 25 年, そ のうち東北や北陸などの積雪地では 10 数年以内で葺き替えが行われ, 逆に 関東南部や近畿地方では平均值を上回る周期が多い。瓦や銅板莫きの屋根 の修理周期は前者に比して 2 から 3 倍長く平均 70 年前後とみることがで きる。」と記載。

注 24）堂宮大工が戦後に設計事務所となる事例や堂宮大工が建設会社となる 事例もある。さらに, 建設会社の中にも社寺を専門とする社寺部が対応する 会社もある等, 堂宮大工の経験を生かした施工を行う建設会社や設計を行 う設計事務所も存在する。なお，堂宮大工とは「寺社建築の修理や建立に係 っている大工」を指し, 一般の大工とは「寺社建築の小修理を除き, 修理や 建立に倸ったことのない大工」を指す。 
IMPACT OF STRUCTURAL ISSUES, etc. ON THE LONG-TERM USE OF CURRENT MAIN HALLS

A questionnaire survey of chief priests of Buddhist temples

\section{Takeshi SASAKI* and Hideaki KATSUMATA**}

*Visiting Researcher, Dept. of Architecture, Faculty of Engineering, Tokyo City University, Dr.Eng.
$* *$ Prof., Dept. of Architecture, Faculty of Engineering, Tokyo City University, Dr.Eng.

This paper is a continuation of the study examining the long-term use of the main halls of temples throughout Japan that are not designated as cultural property by the national government, and the factors thereof.

There are examples of major disasters being experienced during long-term use, and it is essential to conduct maintenance and repairs for the long-term use of old main halls. In this paper, we examine the impact of not only the type of building and era of construction of current main halls, but also factors in structural issues of current main halls, maintenance and repairs, disaster mitigation measures, and advisors on long-term use of current main halls. The following information was revealed.

(1) When comparing three types of buildings, the expected usage period tended to be longer in A. Regional cultural property, but it was found that structural issues were unrelated to the type of construction. Although structural issues were generally found not only in A. Regional cultural property, but also B. No reconstruction and C. Other, they were resolved in all building types by repeated repairs, suggesting that this leads to long-term use.

(2) Structural issues in wooden main halls have gradually decreased in the 70 years since the war, and the rate of structural issues in pre-war construction including reconstruction in the Edo Period remains unchanged around 80 percent.

Structural issues in current main halls may be considered to be a result of long-term use. The expected usage period in the future differs by 60 years depending on whether or not there are any structural issues, and it could be said that structural issues need to be resolved to enable long-term use in the future.

(3) Current main halls (of wooden construction) face aging, etc. of roofing materials and structural materials. Furthermore, causes of structural issues include deterioration due to age, leaks, humidity, ventilation, foundations and termites, and many have complex factors. However, deterioration due to age that has a gradual impact over time could be seen to be a phenomenon that occurs uniformly across all buildings left without maintenance and repairs. Therefore, the removal of human problems such as roof maintenance and repairs, etc. are required for long-term use.

(4) Earthquakes are the type of disaster most commonly experienced in current wooden main halls, and damage included cracking and flaking of walls, collapsed roofing and tiles, inclination of entire buildings and inclination of columns. Furthermore, disaster mitigation measures include the reinforcement of columns and crossbeams, seismic diagnosis, establishment of new walls, use of more lightweight roofing materials and reinforcement of lattices, and 40 percent of seismic diagnoses only involved diagnosis. The motivation for implementing measures to address disasters was more preventative than due to experiencing a disaster, but the overall rate of implementation was not high at only $36 \%$ of all temples.

Advisors for measures to address disasters in current wooden main halls were temple and shrine carpenters, architects, construction companies and ordinary carpenters, and the rate of implementation of seismic diagnosis was high for temple and shrine carpenters.

Meanwhile, all items were implemented less frequently by ordinary carpenters than by other occupations, and ordinary carpenters were consulted most frequently about measures in older current main halls.

The study is based on a questionnaire survey of priests, and does not conduct specific examination of examples of renovation of current main halls by temple and shrine carpenters and ordinary carpenters. In future, examining the effectiveness of renovation including structural stability and the preservation of cultural value based on multiple specific examples of renovation is believed to be an important perspective. 